\title{
Clinical spectrum of scrub typhus in Eastern India: A 3 year experience
}

\author{
Suprit Basu ${ }^{1}$, Sarbani Misra (Roy) ${ }^{2}$, Tanushree Mondal ${ }^{3},{ }^{*}$ Md Maidul Islam ${ }^{4}$, Sumantra Sarkar $^{5}$, Mrinal \\ Kanti Das ${ }^{6}$, Malay Kumar Sinha ${ }^{6}$, Sumana Datta (Kanjilal) ${ }^{6}$, Supratim Datta ${ }^{6}$
}

Sri Lanka Journal of Child Health, 2021; 50(4): 610-616

DOI: http://doi.org/10.4038/sljch.v50i4.9847

\begin{abstract}
Introduction: Scrub typhus is a serious public health problem in Eastern India.
\end{abstract}

Objectives: To study the clinical spectrum and complications of scrub typhus and its doxycycline responsiveness.

Method: This study was carried out over a 3 year period on 203 serologically confirmed scrub typhus cases in a tertiary care centre in Eastern India.

Results: Fever (100\%), facial puffiness (66.5\%), vomiting (51.7\%) and headache (39.4\%) were common symptoms whilst hepatosplenomegaly $(61.6 \%)$ and generalised lymphadenopathy $(60.1 \%)$ were common signs. Meningoencephalitis (33.4\%) and shock $(26.6 \%)$ were common complications. Shock, congestive heart failure (CHF), disseminated intravascular coagulation (DIC), haemophagocytic lymphohistiocytosis (HLH) had delayed response to doxycycline therapy.

Conclusions: In this study meningoencephalitis and shock were the common complications of scrub typhus. Meningo-encephalitis, hepatitis and pneumonia had favourable doxycycline response whilst shock, CCF. DIC, HLH and AKI had delayed doxycycline response $(\mathrm{p}<0.05)$.

\footnotetext{
${ }_{1}^{1}$ Assistant Professor, Paediatrics, Institute of Postgraduate Medical Education and Research, Kolkata, India, ${ }^{2}$ Associate Professor, Paediatrics, Malda Medical College, West Bengal, India, ${ }^{3}$ Associate Professor, Community Medicine, Medical College, Kolkata, India, ${ }^{4}$ Junior Resident, Paediatrics, Institute of Postgraduate Medical Education and Research, Kolkata, India, 5Professor, Paediatrics, Diamond Harbour Medical College, Kolkata, India, ${ }^{6}$ Professor, Paediatrics, Institute of Postgraduate Medical Education and Research, Kolkata, India

*Correspondence: maidulislam0710@gmail.com
}

https://orcid.org/0000-0002-1800-8823 (Keceived on 07 October 2020: Accepted after revision on 20 November 2020)

The authors declare that there are no conflicts of interest.

Personal funding was used for the project.

Open Access Article published under the Creative Commons Attribution CC-BY@C (i) License
(Key words: Scrub typhus, Eastern India, Trend, Doxycycline response, Complications)

\section{Introduction}

Scrub typhus is the commonest rickettsial infection in India leading to multi-organ dysfunction ${ }^{1,2}$. It accounts for about $23 \%$ of febrile illness in India ${ }^{3}$. Isolated case reports and case series have been reported from different parts of India ${ }^{4-6}$. However, extensive data on scrub typhus indicating disease trend have not been reported from Eastern Indiaa ${ }^{2,5,6}$.

\section{Objectives}

To study the clinical spectrum and complications of scrub typhus and its doxycycline responsiveness over a period of three years in a tertiary care hospital in Eastern India.

\section{Method}

An observational study was conducted in the Paediatric Department of IPGME\&R and SSKM Hospital, Kolkata, India, from January 2017 to December 2019. Scrub typhus was suspected in cases having one or more of the following:

- Acute undifferentiated fever of more than 5 days ( $<5$ days if eschar is noted)

- Fever with meningoencephalitis / encephalitis

- Fever with vital organ involvement

- Fever with haemorrhagic manifestations

- Fever with rash / oedema / generalised lymphadenopathy / hepatomegaly / hepatitis with jaundice / dry cough / sepsis of unclear aetiology $\mathrm{y}^{6-9}$.

All patients, aged 12 years or less, clinically suspected of scrub typhus were enrolled in the study. Confirmed scrub typhus was defined as fever $>5$ days + positive IgM serology (TM IgM ELISA system InBiOS International, Inc.Seattle $\mathrm{USA}) \pm$ positive Weil-Felix reaction (OX K 1/80 or $>)^{10,11}$. Defervescence within 48 hours was considered additional confirmatory evidence ${ }^{8,12-14}$. Demographic characteristics and clinical features were recorded in a pre-structured proforma. Doxycycline $4.5 \mathrm{mg} / \mathrm{kg} /$ day in 2 divided doses was given for 7-14 days in laboratory confirmed cases 7 . Time to achieve defervescence and complications were noted. Complete blood count, erythrocyte sedimentation rate, C-reactive protein, liver function tests, renal function tests, serum albumin, 
serum electrolytes and chest $\mathrm{x}$-ray were done in all cases at admission and repeated as required. Electrocardiogram and echocardiography were done in cases with congestive cardiac failure. Serum ferritin and serum triglyceride levels were estimated in haemophagocytic lymphohistiocytosis (HLH) suspected cases. Cerebrospinal fluid (CSF) assay was done in patients with neurological presentation. Differential diagnoses like dengue, malaria, infectious mononucleosis, septicaemia, pneumonia, leptospirosis, typhoid and urinary tract infection were ruled out in appropriate cases.

Ethical Issues: Ethical approval was obtained from the Ethics Committee of the Institute of Postgraduate Medical Education \& Research, Kolkata (No: Inst/IEC/2018/031). Written informed consent was obtained from the parents and assent, if the child was more than 7 years of age.

Statistical analysis: Categorical variables were expressed as frequency and percentages whilst continuous variables were expressed as mean and standard deviation. Comparison of groups was done using ANOVA, Student t-test and Chi-square test. $p<0.05$ was considered significant. SPSS version 20 was used for the statistical analysis.

\section{Results}

Of 305 patients presenting with fever and features suggestive of scrub typhus, $203(66.6 \%)$ were confirmed as scrub typhus. Mean age of the cohort was 6.3 years with a minimum age of 4 months and a maximum age of 12 years. We had $56.2 \%$ males and $43.8 \%$ females. One hundred (54\%) children were from rural and $85(46 \%)$ from urban areas. Most (85\%) cases occurred from July to November. Duration of fever ranged from 3 to 18 days with a mean duration of 9.2 days. Three patients had multiple eschars. Common sites were perineal region $(45 \%)$ followed by axilla $(15 \%)$. Eschar was associated with regional lymphadenopathy in $80(90 \%)$ cases. Table 1 shows the clinical and laboratory parameters at presentation and complications over 3 years. Figure 1 is a bar diagram showing clinical features over the 3 years. Figure 2 is a bar diagram showing complications over the 3 years.

Table 1: Trend of clinical and laboratory parameters at presentation and complications over 3 years

\begin{tabular}{|c|c|c|c|c|}
\hline Parameter & $2017(\mathrm{n}=61)$ & $2018(n=60)$ & $2019(n=82)$ & Total $(n=203)$ \\
\hline $\begin{array}{l}\text { Clinical features } \\
\text { Mean age of presentation (years) } \\
\text { Male: female } \\
\text { Fever }>7 \text { days - n (\%) } \\
\text { Headache - n (\%) } \\
\text { Myalgia - n (\%) } \\
\text { Facial puffiness - n (\%) } \\
\text { Seizures - n (\%) } \\
\text { Cough - n (\%) } \\
\text { Pain in abdomen - n (\%) } \\
\text { Vomiting - n (\%) } \\
\text { Eschar - n (\%) } \\
\text { Pedal oedema - n (\%) } \\
\text { Rash - n (\%) } \\
\text { Meningeal signs - n (\%) } \\
\text { Lateral rectus palsy - n (\%) } \\
\text { Icterus - n (\%) } \\
\text { Generalised lymphadenopathy - n (\%) } \\
\text { Hepato-splenomegaly - n (\%) } \\
\text { Splenomegaly without hepatomegaly - n (\%) }\end{array}$ & $\begin{array}{c}6.1 \\
32: 29(1.1: 1) \\
47(77.0) \\
28(45.9) \\
15(24.6) \\
41(67.2) \\
07(11.5) \\
24(39.3) \\
33(54.1) \\
39(63.9) \\
30(49.2) \\
32(52.5) \\
12(19.7) \\
19(31.1) \\
05(08.2) \\
02(03.3) \\
36(59.0) \\
32(52.5) \\
01(01.6) \\
\end{array}$ & $\begin{array}{c}6.0 \\
35: 25(1.4: 1) \\
45(75.0) \\
20(33.3) \\
15(25.0) \\
40(66.6) \\
10(16.7) \\
20(33.3) \\
22(36.7) \\
25(41.7) \\
26(43.3) \\
35(38.3) \\
05(08.3) \\
21(35.0) \\
03(05.0) \\
05(08.3) \\
35(58.3) \\
40(66.6) \\
06(10.0) \\
\end{array}$ & $\begin{array}{c}6.7 \\
47: 35(1.3: 1) \\
72(87.8) \\
32(39.0) \\
29(35.3) \\
54(65.8) \\
19(23.2) \\
28(34.1) \\
23(28.0) \\
41(50.0) \\
33(40.2) \\
45(54.8) \\
16(19.5) \\
26(31.7) \\
04(04.9) \\
14(17.1) \\
51(62.1) \\
53(64.6) \\
10(12.2) \\
\end{array}$ & $\begin{array}{c}6.3 \\
114: 89(1.3: 1) \\
164(80.7) \\
80(39.4) \\
59(29.0) \\
135(66.5) \\
36(17.7) \\
72(35.5) \\
78(38.4) \\
105(51.7) \\
89(43.8) \\
112(55.2) \\
33(16.2) \\
66(32.5) \\
12(05.9) \\
21(10.3) \\
122(60.1) \\
125(61.6) \\
17(08.3) \\
\end{array}$ \\
\hline $\begin{array}{l}\text { Laboratory parameters } \\
\text { Anaemia for age - n (\%) } \\
\text { Thrombocytopenia - n (\%) } \\
\text { Neutrophilic leucocytosis - n (\%) } \\
\text { Hyponatraemia - n (\%) } \\
\text { Hypoalbuminaemia - n (\%) } \\
\text { Raised SGOT - n (\%) } \\
\text { Raised C-reactive protein - n (\%) }\end{array}$ & $\begin{array}{l}51(83.6) \\
36(59.0) \\
50(82.0) \\
31(49.2) \\
34(55.7) \\
17(27.9) \\
60(98.3)\end{array}$ & $\begin{array}{l}50(83.3) \\
25(41.7) \\
35(58.3) \\
30(50.0) \\
25(41.7) \\
15(25.0) \\
54(90.0)\end{array}$ & $\begin{array}{l}66(80.4) \\
51(62.2) \\
60(73.2) \\
50(60.9) \\
38(46.3) \\
33(40.2) \\
75(91.4)\end{array}$ & $\begin{array}{c}167(82.2) \\
112(55.1) \\
145(71.4) \\
111(54.6) \\
97(47.8) \\
63(31.0) \\
189(93.1)\end{array}$ \\
\hline $\begin{array}{l}\text { Complications } \\
\text { Meningoencephalitis - n (\%) } \\
\text { Shock - n (\%) } \\
\text { Disseminated intravascular coagulation - n (\%) } \\
\text { Haemophagocytic lymphohistiocytosis - n (\%) } \\
\text { Acute kidney injury - n (\%) } \\
\text { Hepatitis - n (\%) } \\
\text { Pneumonia - n (\%) } \\
\text { Congestive heart failure - n (\%) }\end{array}$ & $\begin{array}{l}21(34.4) \\
17(27.9) \\
04(06.5) \\
08(13.1) \\
03(04.9) \\
02(03.2) \\
06(09.8) \\
06(09.8)\end{array}$ & $\begin{array}{l}20(33.3) \\
14(23.3) \\
05(08.3) \\
10(16.6) \\
02(03.3) \\
05(08.3) \\
12(20.0) \\
09(15.0)\end{array}$ & $\begin{array}{l}27(32.9) \\
23(28.0) \\
04(04.8) \\
03(03.6) \\
04(04.8) \\
10(12.2) \\
19(23.2) \\
20(24.4)\end{array}$ & $\begin{array}{l}68(33.4) \\
54(26.6) \\
13(06.4) \\
21(10.3) \\
09(04.4) \\
17(08.3) \\
37(18.2) \\
35(17.2)\end{array}$ \\
\hline
\end{tabular}




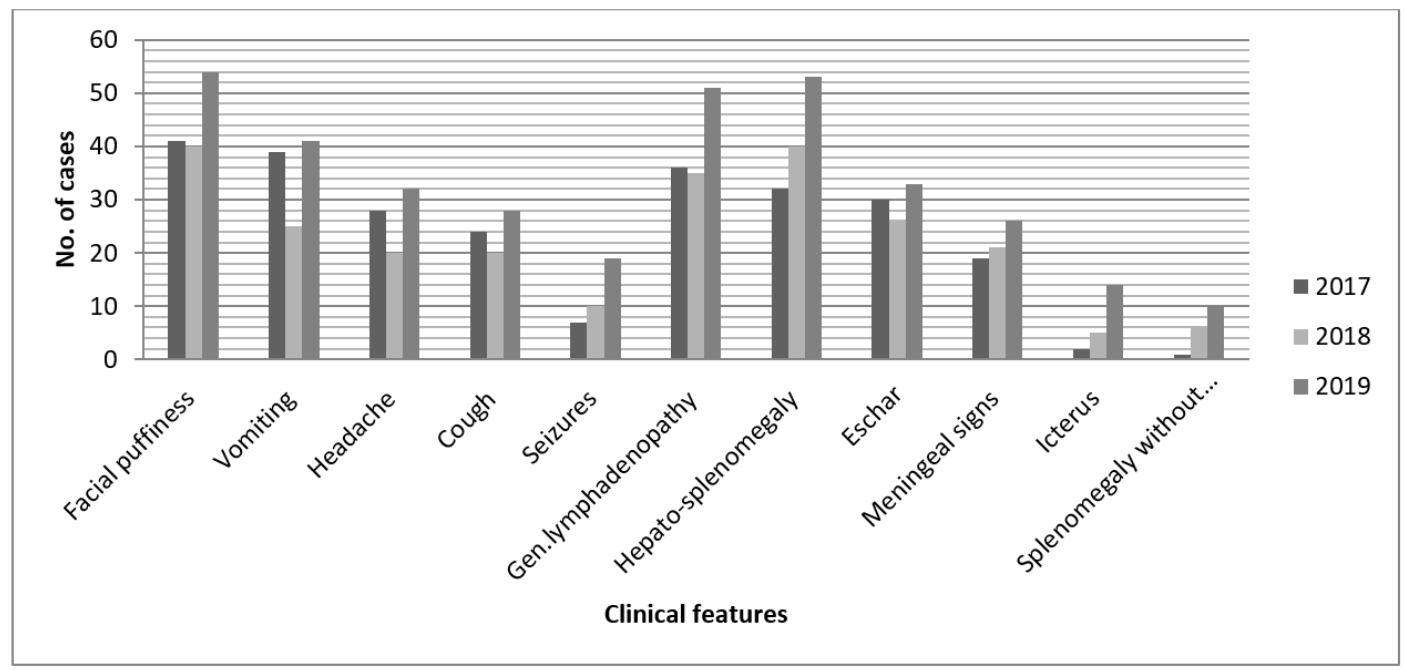

Figure 1: Bar diagram showing clinical features over the 3 years

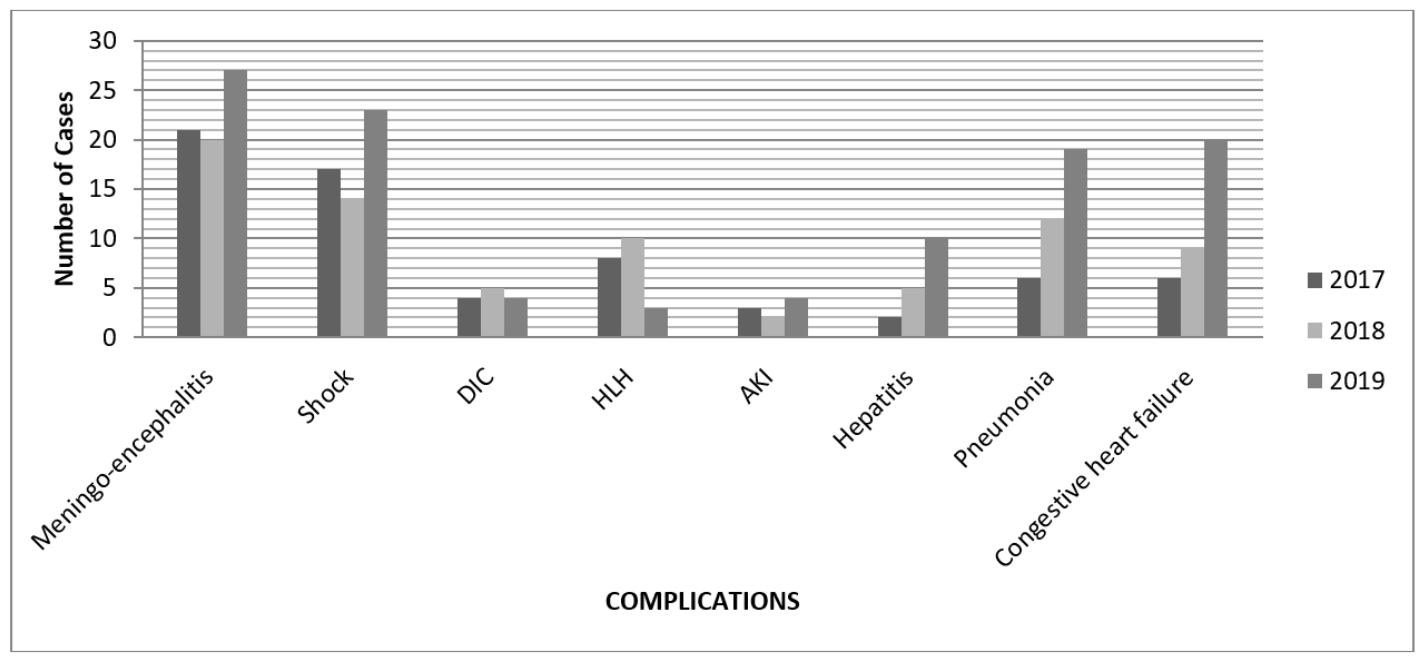

Figure 2: Bar diagram showing complications over the 3 years

Scrub meningoencephalitis was present in 68 cases, 54 of them having lymphocytic pleocytosis and 57 had raised protein in the CSF analysis. Ferritin level was estimated in $31(15.3 \%)$ patients of HLH. Mean value was $6005.8 \mathrm{ng} / \mathrm{ml}$, maximum being $31,000 \mathrm{ng} / \mathrm{ml}$. Serum triglyceride was raised in 25 patients $($ mean $=350.6 \mathrm{mg} / \mathrm{dl})$. Response to doxycycline, assessed by defervescence, was documented in all survivors with mean duration of response 53.4 hours. Among them 155 (77.2\%) had a response within 48 hours whereas $46(22.8 \%)$ had delayed response ( $>48$ hours) (Table 2). Neutrophilic leucocytosis, thrombocytopenia, hyponatremia and raised CRP had positive correlation $(p<0.05)$ with delayed doxycycline response. Intensive care was required in $37(18.3 \%)$ patients. Inotrope support and mechanical ventilation were required in $32(15.7 \%)$ and 10 $(4.9 \%)$ cases respectively.

Table 2: Doxycycline responsiveness of various complications

\begin{tabular}{|c|c|c|c|c|}
\hline \multirow[t]{2}{*}{ Complication } & \multicolumn{3}{|c|}{ Doxycycline response $(n=201)$} & \multirow{2}{*}{$\begin{array}{c}\text { No response to } \\
\text { doxycycline }(n=2)\end{array}$} \\
\hline & 48 hours or $<(n=155)$ & $>48$ hours $(n=46)$ & p-value & \\
\hline Shock - n (\%) & $20(37.0)$ & $34(63.0)$ & $<0.05$ & 0 \\
\hline CNS involvement - $\mathrm{n}(\%)$ & $55(80.8)$ & $13(19.2)$ & 0.464 & 0 \\
\hline CCF - n (\%) & $16(45.7)$ & $19(54.3)$ & $<0.05$ & 1 \\
\hline HLH - n (\%) & $13(61.9)$ & $08(38.1)$ & $<0.05$ & 1 \\
\hline AKI - n (\%) & $05(55.0)$ & $04(45.0)$ & $<0.05$ & 0 \\
\hline Pneumonia - n (\%) & $29(78.4)$ & $08(21.6)$ & 0.839 & 0 \\
\hline Hepatitis - n (\%) & $15(88.2)$ & $02(11.8)$ & 0.367 & 0 \\
\hline DIC - n (\%) & $05(38.5)$ & $08(61.5)$ & $<0.05$ & 0 \\
\hline
\end{tabular}

CNS: central nervous system, CCF: congestive cardiac failure, $H L H$ : haemophagocytic lymphohistiocytosis, AKI: acute kidney injury, DIC: disseminated intravascular coagulation 
Only one patient with HLH required definitive management as per standard protocol. Two cases succumbed, one from HLH with multi-organ dysfunction syndrome (MODS) in 2017 and another from congestive cardiac failure (CCF) in 2019. Meningo-encephalitis, hepatitis and pneumonia cases had favourable doxycycline response while other complications were associated with delayed doxycycline response, which was statistically significant $(p<0.05)$. Co-infection with infectious mononucleosis and dengue were detected in 5 and 4 patients respectively. All had prompt doxycycline response.

\section{Discussion}

Scrub typhus is transmitted to humans by the bites of chigger infected with Orientia tsutsugamushi ${ }^{4,12}$. If appropriate treatment is not administered, complications develop by the second week $^{15}$. Immunofluorescence assay, the 'gold standard' to diagnose rickettsial infection, is costly and not freely available ${ }^{16}$. Scrub typhus specific ELISA based IgM assay is the most sensitive test for diagnosis after one week of illness ${ }^{1}$. We had male preponderance (1.3:1) in our study similar to study by Bhat NK, et $a l^{8}$. Rash was found in $16.2 \%$ of our patients similar to some studies ${ }^{8,13}$. Higher incidence of rash $(23 \%$ to $100 \%)$ was reported by others ${ }^{17}$. Fever was present in all cases. Most of the cases $(80.7 \%)$ presented with prolonged fever $(>7$ days). Facial puffiness $(66.5 \%)$, vomiting $(51.7 \%)$ headache $(39.4 \%)$ and pain in abdomen $(38.4 \%)$ were common presenting symptoms in our study and the trend was similar in all 3 years, which is comparable to other studies $8,10,17,18$.

Common presenting signs were hepatosplenomegaly $(61.6 \%), \quad$ generalised lymphadenopathy $(60.1 \%)$ and pedal oedema $(55.2 \%)$ similar to other studies ${ }^{1,17,19}$. The trend was similar in all 3 years. We found increasing trend of icterus $(3.3 \%$ in 2017 to $17.1 \%$ in 2019$)$ and splenomegaly without hepatomegaly (1.6\% in 2017 to $12.2 \%$ in 2019) in our study (Table 1). Splenomegaly, found in scrub typhus can help differentiate it from dengue infection. Eschar was present in $43.8 \%$ of cases. Multiple eschars, found in several studies ${ }^{20}$, were found in 3 of our cases. Careful and thorough physical examination helped in eschar identification and early diagnosis. An eschar, though pathognomonic of chigger bite, is found in $7 \%-97 \%$ of cases ${ }^{6,11,21}$.

Haematological abnormalities on laboratory investigation showed anaemia (82.2\%), neutrophilic leucocytosis (71.4\%) and thrombocytopenia $(55.1 \%)$, which is similar to other studies ${ }^{1,8,14,16}$. The haematological abnormalities had similar trends in all 3 years. Meningo-encephalitis (33.4\%) with CSF lymphocytic pleocytosis was similar to study by Kumar M, et $a l^{19}$. Doxycycline responsiveness was studied. Among doxycycline responders $(n=201)$, mean duration of response was 53.4 hours. Though most cases $(n=155)$ responded within 48 hours, patients with $\mathrm{HLH}$, shock, $\mathrm{CCF}$ took much more time to respond shifting the mean response time higher. Neutrophilic leucocytosis, thrombocytopenia, raised C-reactive protein (CRP), hyponatraemia showed significant association with delayed doxycycline response.

Incidence of meningo-encephalitis remained almost similar in the 3 years, comprising one-third of cases. Lateral rectus palsy at presentation, though rare, was found in $12(5.9 \%)$ cases in the first week of illness similar to case series ${ }^{22,23}$. The major life threatening complications were shock, HLH, CCF and disseminated intravascular coagulation (DIC). High incidence of shock (26.6\%) similar to study by Bhat $\mathrm{NK}$, et $a l^{8}$ was found in our study. We found a similar trend of shock, CCF and DIC in all 3 years. There is an increase in incidence of scrub pneumonia and scrub hepatitis cases over the 3 years (Table 1). One notable trend was a significant reduction in HLH cases (13.1\% in 2017 to $3.6 \%$ in $2019)$ over the 3 years $(\mathrm{p}<0.05)$ most probably due to increased awareness and early institution of doxycycline therapy preventing the progression to HLH. Case mortality rate in our study was $0.98 \%$ similar to study by Basu $\mathrm{S}$, et $\mathrm{al}^{24}$. One case died from complications of $\mathrm{HLH}$ and the other from CCF. Both HLH and CCF are two dreaded complications, reported in severe infection ${ }^{24,25}$.

We had some rare presentations of scrub typhus in the form of bilateral epididymo-orchitis, acute cholecystitis with cholelithiasis, acute pancreatitis and gangrene of hand, all of which responded to doxycycline therapy. We also had a case of Guillain-Barre syndrome following scrub typhus infection. These are very rare manifestations of scrub typhus ${ }^{26-29}$.

Scrub meningo-encephalitis and scrub pneumonia had prompt doxycycline response. However, shock, CCF, DIC, HLH and acute kidney injury (AKI) had delayed doxycycline response which was statistically significant. This delayed response may be due to hypoperfusion leading to poor absorption or due to severity of disease or decreased immunity of the infected host. Similar views have been made by other authors ${ }^{24,26}$. Infection by doxycycline resistant strain or virulent strains of the organism may be another factor for delayed response, though the literature suggests that doxycycline resistance is $\operatorname{rare}^{30}$. 


\section{Conclusions}

In this study meningoencephalitis and shock were the common complications of scrub typhus. Meningo-encephalitis, hepatitis and pneumonia cases had favourable doxycycline response whilst shock, CCF. DIC, HLH and AKI had delayed doxycycline response which was statistically significant $(\mathrm{p}<0.05)$.

Acknowledgements: The authors are thankful to all the faculties and postgraduate trainees of Department of Paediatrics, I.P.G.M.E. \& R. Kolkata, for their help.

\section{References}

1. Silpapojakul K. Scrub typhus in the Western Pacific region. Annals of the Academy of Medicine Singapore 1997; 26(6): 794-800.

2. Varghese GM, Trowbridge $P$, Janardhanan J, Thomas K, Peter JV, Mathews $\mathrm{P}$, et al. Clinical profile and improving mortality trend of scrub typhus in South India. International Journal of Infectious Diseases 2014; 23: 39-43.

https://doi.org/10.1016/j.ijid.2014.02.009

PMid: 24661931

3. Chunchanur SK. Scrub typhus in India An impending threat! Annals of Clinical Immunology and Microbiology 2018; 1(1): 3.

4. Rathi N, Rathi A. Rickettsial infections: Indian perspective. Indian Pediatrics 2010; 47(2):157-64.

https://doi.org/10.1007/s13312-010-00243

PMid: 20228429

5. Khan SA, Khamo V, Uriah HJ, Bora T, Dutta P. Scrub typhus in hilly regions of north east India. Indian Journal of Medical Research 2016; 144(1):138-40. https://doi.org/10.4103/0971-5916.193302 PMid: 27834339 PMCid: PMC5116888

6. Rathi N, Kulkarni A, Yewale V, For Indian Academy of Pediatrics Guidelines on Rickettsial Diseases in Children Committee. IAP Guidelines on Rickettsial Diseases in Children. Indian Pediatrics 2017; 54(3): 223-9. https://doi.org/10.1007/s13312-017-10350

PMid: 28361787
7. Rahi M, Gupte MD, Bhargava A, Varghese GM, Arora R. DHR-ICMR Guidelines for Diagnosis \& Management of Rickettsial Diseases in India. Indian Journal of Medical Research 2015; 141(4): 417-22.

https://doi.org/10.4103/0971-5916.159279 PMid: 26112842 PMCid: PMC4510721

8. Bhat NK, Pandita N, Saini M, Dhar M, Ahmed S, Shirazi N, et al. Scrub Typhus: A clinico-laboratory differentiation of children with and without meningitis. Journal of Tropical Pediatrics 2016; 62(3): 194-9.

https://doi.org/10.1093/tropej/fmv097

PMid: 26851433

9. Directorate of health services Government of West Bengal, India. Scrub Typhus Management and Treatment and Request form. wbhealth.gov.in; 2019.

10. Rose W, Ghosh U, Punnen A, Sarkar R, Prakash JJA, Verghese VP. Comparison of scrub typhus with and without meningitis. Indian Journal of Pediatrics 2017; 84(11):833-7. https://doi.org/10.1007/s12098-017-24034

PMid: 28674823

11. Rose W, Rajan RJ, Punnen A, Ghosh U. Distribution of eschar in paediatric scrub typhus. Journal of Tropical Pediatrics 2016; 62(5): 415-20.

https://doi.org/10.1093/tropej/fmw027

PMid: 27122479

12. Panpanich R, Garner P. Antibiotics for treating scrub typhus. Cochrane Database Systematic Reviews 2002; (3): CD002150.

13. Kumar Bhat N, Dhar M, Mittal G, Shirazi N, Rawat A, Prakash Kalra B, et al. Scrub typhus in children at a tertiary hospital in North India: Clinical profile and complications. Iranian Journal of Pediatrics 2014; 24(4): 387-92.

14. Huang C-T, Chi H, Lee H-C, Chiu N-C, Huang F-Y. Scrub typhus in children in a teaching hospital in eastern Taiwan, 20002005. Southeast Asian Journal of Tropical Medicine and Public Health 2009; 40(4): 789-94. 
15. Sriwongpan P, Krittigamas P, Tantipong $\mathrm{H}$, Patumanond J, Tawichasri C, Namwongprom S. Clinical risk-scoring algorithm to forecast scrub typhus severity. Risk Management and Healthcare Policy 2013; 7:11-7.

https://doi.org/10.2147/RMHP.S55305

PMid: 24379733 PMCid: PMC3872011

16. Kalal BS, Puranik P, Nagaraj S, Rego S, Shet A. Scrub typhus and spotted fever among hospitalised children in South India: Clinical profile and serological epidemiology. Indian Journal of Medical Microbiology 2016; 34(3): 293.

https://doi.org/10.4103/0255-0857.188315 PMid: 27514949

17. Palanivel S, Nedunchelian K, Poovazhagi V, Raghunadan R, Ramachandran P. Clinical profile of scrub typhus in children. Indian Journal of Pediatrics 2012; 79(11): 1459-62. https://doi.org/10.1007/s12098-012-07210

PMid: 22374234

18. Mathai E, Lloyd G, Cherian T, Abraham OC, Cherian AM. Serological evidence for the continued presence of human rickettsioses in southern India. Annals of Tropical Medicine and Parasitology 2001; 95(4): 395-8.

https://doi.org/10.1080/000349801200658 04

PMid: 11454249

19. Kumar M, Krishnamurthy S, Delhikumar CG, Narayanan P, Biswal N, Srinivasan S. Scrub typhus in children at a tertiary hospital in southern India: clinical profile and complications. Journal of Infection and Public Health 2012; 5(1): 82-8. https://doi.org/10.1016/j.jiph.2011.11.001 PMid: 22341847

20. Kundavaram AP, Jonathan AJ, Nathaniel SD, Varghese GM. Eschar in scrub typhus: A valuable clue to the diagnosis. Journal of Postgraduate Medicine 2013; 59(3): 177.

https://doi.org/10.4103/0022-3859.118033 PMid: 24029193

21. Paris DH, Shelite TR, Day NP, Walker DH. Unresolved problems related to scrub typhus: a seriously neglected lifethreatening disease. American Journal of Tropical Medicine and Hygiene 2013; 89(2): 301-7. https://doi.org/10.4269/ajtmh.13-0064

PMid: 23926142 PMCid: PMC3741252

22. Viswanathan $\mathrm{S}$, Muthu $\mathrm{V}$, Iqbal $\mathrm{N}$, Remalayam B, George T. Scrub typhus meningitis in South India - A retrospective study. PloS One 2013; 8(6): e66595.

https://doi.org/10.1371/journal.pone.0066 595

PMid: 23799119 PMCid: PMC3682970

23. Garg RK. Tuberculous meningitis. Acta Neurologica Scandinavica 2010; 122(2): 75-90.

https://doi.org/10.1111/j.16000404.2009.0

1316.x

PMid: 20055767

24. Basu S, Saha A, Sarkar S, Sinha MK, Das MK, Datta $\mathrm{R}$, et al. Clinical profile and therapeutic response of scrub typhus in children: A recent trend from Eastern India. Journal of Tropical Pediatrics 2019; 65(2): 139-46.

https://doi.org/10.1093/tropej/fmy027

PMid: 29800384

25. Jin Y, Huang L, Fan H, Lu G, Xu Y, Wu Z. Scrub typhus associated with haemophagocytic lymphohistiocytosis: A report of six paediatric patients. Experimental and Therapeutic Medicine 2016; 12(4): 2729-34.

https://doi.org/10.3892/etm.2016.3668

PMid: 27698778 PMCid: PMC5038170

26. Prasannan A, Ramaswamy P, Anirudhan VK. Rickettsial fever presenting with gangrene: A case series. Journal of Clinical and Diagnostic Research 2017; 11(6): PR01-3.

https://doi.org/10.7860/JCDR/2017/25371 .10024

PMid: 28764251 PMCid: PMC5535442

27. Saha A, Sarkar S, Patil A, Besra B, Saha C. Epididymo-orchitis in Scrub Typhus. Indian Journal of Pediatrics 2018; 85(11):1035-6. https://doi.org/10.1007/s12098-018-26824

PMid: 29675739

28. Ahmed ASI, Kundavaram APP, Sathyendra S, Abraham OC. Acute pancreatitis due to Scrub Typhus. Journal of Global Infectious Diseases 2014; 6(1):31-4. 
https://doi.org/10.4103/0974777X.127949

PMid: 24741229 PMCid: PMC3982354

29. Lee H, Ji M, Hwang J-H, Lee J-Y, Lee J$\mathrm{H}$, Chung KM, et al. Acute cholecystitis in patients with Scrub Typhus. Journal of Korean Medical Science 2015; 30(11):1698-700.

https://doi.org/10.3346/jkms.2015.30.11.1 698

PMid: 26539017 PMCid: PMC4630489
30. Wangrangsimakul T, Phuklia W, Newton PN, Richards AL, Day NPJ. Scrub typhus and the misconception of doxycycline resistance. Clinical Infectious Diseases 2020; 70(11): 2444-9. https://doi.org/10.1093/cid/ciz972

PMid: 31570937 PMCid: PMC7245148 